\title{
PENAPISAN JAMUR DAN BAKTERI ANTAGONIS TERHADAP JAMUR AKAR PUTIH (Rigidoporus microporus) DARI RIZOSFER TANAMAN LIDAH MERTUA (Sansevieria trifasciata Prain)
}

\author{
Screening on Antagonistic Fungi and Bacteria to White Root Fungi (Rigidoporus \\ microporus) from Snake Plant Rizosphere (Sansevieria trifasciata Prain)
}

Tri Rapani FEBBIYANTI

Balai Penelitian Sembawa, Pusat Penelitian Karet

J1. Raya Palembang - P. Balai KM 29, PO BOX 1127 Palembang 30001

Diterima tanggal 11 April 2012 / Disetujui tanggal 10 Juli 2012

\begin{abstract}
White root disease caused by Rigidoporus microporus is an important disease in rubber plantation which might make high economic losses in rubber plantation in Indonesia. Since 2003, Sembawa Research Centre has obtained an alternative control that is cheap, practical and easy to be implemented by farmer, i.e by using antagonistic plants. Antagonistic plants are commonly available at the localities and they have capabilities for suppressing the development of white root disease. The antagonistic plants affect directly and indirectly the development of white root disease pathogen in the soil. The main factor directly affecting the pathogen is the exudates of antibiotic by the plant roots, whilst the secondary factors indirectly influencing the pathogen are the biochemical-physical properties of soil. Of the 12 antagonistic plants tested in the field, snake plant (Sansevieria trifasciata Prain) was the most effective one in controlling white root disease because it was more resistant to extreme environmental conditions and had antimicrobial substances. The research was done at laboratory scale to explore the fungi and bacteria found in the rhizosphere of snake plant. The results showed that there were 1 types of bacteria and 7 types of fungi obtained from the rhizosphere of the snake plant. Of the 11 isolates of bacteria, 4 isolate were classified as gram-positive and 7 isolates as gramnegative. It was found that isolates L.M. 5 and L.M. 6 were antagonistic to Rigidoporus microporus. Among 7 isolates of fungi, 4 isolates were found antagonistic to Rigidoporus microporus.
\end{abstract}

Keywords : Hevea brasiliensis, white root fungi, bacteria, fungi, screening, Sansevieria trifasciata

\begin{abstract}
Abstrak
Penyakit jamur akar putih yang disebabkan oleh jamur Rigidoporus microporus merupakan salah satu penyakit penting di perkebunan karet karena mengakibatkan kerugian yang cukup berarti. Mulai tahun 2003, Balai Penelitian Sembawa telah memperoleh suatu pengendalian alternatif yang murah, mudah didapat dan diterapkan di perkebunan rakyat yaitu pemanfaatan tumbuhan antagonis. Tumbuhan antagonis adalah suatu tumbuhan dari alam sekitar yang mempunyai kemampuan untuk menekan atau menghambat perkembangan penyakit akar putih. Tumbuhan antagonis memberikan pengaruh langsung dan tidak langsung terhadap perkembangan jamur akar putih dalam tanah. Faktor utama yang berpengaruh secara langsung adalah eksudat akar yang bersifat antibiotik, sedangkan faktor sekunder yang berpengaruh secara tidak langsung adalah sifat biokimia-fisik tanah. Dari 12 tumbuhan antagonis yang telah diuji di lapangan, lidah mertua (Sanseviera trifasciata Prain) merupakan tanaman yang paling efektif dalam mengendalikan jamur akar putih karena tanaman tersebut lebih tahan terhadap kondisi lingkungan yang ektrim dan adanya zat anti mikroba pada tumbuhan ini. Penelitian ini bertujuan untuk mengeksplorasi jamur dan bakteri yang terdapat di rizosfer tanaman lidah mertua secara laboratorium. Hasil penelitian menunjukkan bahwa terdapat 11 jenis bakteri dan 7 jenis jamur yang diperoleh dari rizosfer lidah mertua. Dari 11 isolat bakteri tersebut, 4 diantaranya tergolong bakteri gram positif dan 7 tergolong bakteri gram negatif, kemudian terdapat suatu interaksi
\end{abstract}


antagonisme antara isolat bakteri L. M. 5 dan L. M. 6 dengan jamur Rigidoporus microporus. Kemudian, dari 7 isolat jamur yang ditemukan terdapat 4 isolat jamur yang merupakan jamur antagonis terhadap jamur Rigidoporus microporus.

Kata kunci: Hevea brasiliensis, jamur akar putih, bakteri, jamur, penapisan, Sansevieria trifasciata

\section{PENDAHULUAN}

Penyakit akar putih yang disebabkan oleh jamur Rigidoporus microporus merupakan penyakit penting dan mengakibatkan kerusakan pada akar tanaman karet. Serangan patogen menyebabkan akar menjadi busuk dan ditumbuhi miselia jamur, sehingga akar tidak mampu lagi menyerap air dan hara mineral dari tanah dan menyebabkan tanaman karet menjadi mati.

Mulai tahun 2003, di Balai Penelitian Sembawa telah dilakukan penelitian untuk mendapatkan tumbuhan antagonis yang efektif menekan perkembangan penyakit akar putih. Tumbuhan antagonis memberikan pengaruh langsung dan tidak langsung terhadap perkembangan jamur akar putih dalam tanah. Faktor utama yang berpengaruh secara langsung adalah eksudat akar yang bersifat antibiotik, sedangkan faktor sekunder yang berpengaruh secara tidak langsung adalah sifat biokimia-fisik tanah. Tumbuhan antagonis yang diuji adalah temu lawak, laos, lempuyang, kunyit, garut, sigsag, lidah mertua, cocor bebek, pandan hutan, sambiloto, sirih dan serai. Pemilihan tumbuhan ini didasarkan atas adanya kandungan antimikrobia (Wijayakusuma et al., 1995, 1996; Dalimartha, 2000; Mursito, 2000).

Adanya antibiotik yang dilepaskan akar tumbuhan antagonis ke dalam tanah diduga merupakan faktor utama yang berperan dalam mekanisme antagonisme tumbuhan tersebut terhadap jamur akar putih (Situmorang et al. 2007). Pada daerah permukaan akar tanaman dan di daerah sekitar akar banyak terdapat eksudat akar yang berasal dari proses metabolisme tanaman yang dilepaskan ke dalam tanah melalui akar (Purwaningsih, 2003). Eksudat akar menghasilkan makanan dasar yang mendukung pertumbuhan mikroorganisme antagonis seperti asam amino (Rao, 1994), dan eksudat tersebut dimanfaatkan oleh mikroba tanah untuk dapat bertahan hidup serta berkembang biak.

Eksudat akar yang dihasilkan oleh tumbuhan antagonis tersebut selain bersifat antibiotik juga mempengaruhi faktor biotik dan abiotik dalam tanah. Faktor biotik dan abiotik dapat mempengaruhi perkembangan jamur akar putih dalam tanah (Situmorang et al., 2007). Faktor biotik yang mempengaruhi adalah beberapa jenis mikrobia tanah (bakteri, aktinomiset, dan jamur) yang bersifat antagonis (parasitik, antibiotik, dan kompetisi), dan tumbuhan antagonis yang dapat menghasilkan eksudat antimikrobia terhadap jamur akar putih. Sementara faktor abiotik yang berpengaruh adalah sifat kimia-fisik tanah yaitu keasaman tanah, kelembaban, dan struktur tanah (Situmorang et al., 2007)

Hasil pengujian di lapangan diperoleh dua jenis tanaman antagonis yang efektif terhadap jamur akar putih yaitu kunyit dan lidah mertua. Namun, kunyit tidak tahan terhadap kondisi ektrim (kekeringan) sehingga akan mati, sedangkan lidah mertua mampu bertahan pada kondisi lingkungan yang ekstrim (kering) dan terdapat eksudat yang bersifat anti mikroba yaitu abamagenin (Situmorang et al., 2007).

Berdasarkan uraian sebelumnya, maka perlu dilakukan ekplorasi (isolasi) mikroba terutama bakteri dan jamur yang di terdapat pada rhizosfer akar lidah mertua dan uji antagonis untuk mengendalikan penyakit jamur akar putih (Rigidoporus microporus).

\section{BAHAN DAN METODE}

Penelitian dilaksanakan di Laboratorium Proteksi Balai Penelitian Sembawa, Banyuasin, Sumatra Selatan pada bulan Oktober 2008 s.d September 2009. Bahan yang digunakan jamur Rigidoporus microporus dan tanaman antagonis lidah mertua. Cara kerja penelitian yaitu :

1) Pembuatan media NA, MEA dan PDA serta sterilisasi alat dan bahan. 
2) Pengambilan Sampel

Sampel tanah yang digunakan sebagai sumber isolat diambil dari daerah rizosfer tanaman lidah mertua di Kebun Percobaan Balai Penelitian Sembawa. Sampel diambil di sekitar perakaran \pm 10 $\mathrm{cm}$ dari permukaan tanah lidah mertua dan tanaman antagonis lain sebagai pembanding. Sampel ditimbang sebanyak 1 gram, dimasukkan ke dalam tabung reaksi berisi $10 \mathrm{ml}$ aquades (Rao, 1994).

3) Isolasi Bakteri dan Jamur.

Isolasi jamur dilakukan setelah tanah dari daerah rizosfer dihomogenkan, kemudian dibuat pengenceran dengan konsentrasi $10^{-1}$ sampai konsentrasi $10^{-6}$. Sampel dari seri pengenceran dengan konsentrasi $10^{-4}, 10^{-5}, 10^{-6}$ masingmasing diambil sebanyak $0,1 \mathrm{ml}$ dan dimasukkan ke dalam medium NA (Nutrien Agar) dengan suhu $>40^{\circ} \mathrm{C}$ dalam cawan petri kemudian diputar-putar supaya homogen dan didiamkan hingga padat. Semua dilakukan dalam kondisi aseptik dengan menggunakan api bunsen. Kemudian diinkubasi pada suhu $37^{\circ} \mathrm{C}$ di dalam inkubator selama $1 \mathrm{x}$ 24 jam. Setelah diperoleh isolat bakteri, dilanjutkan dengan pemurnian (Susilowati, 2003).

4) Pemurnian Isolat Bakteri

Isolat bakteri yang diperoleh dari isolasi dengan ciri yang berbeda, selanjutnya dimurnikan dengan memindahkan isolat bakteri ke dalam medium Nutrien Agar (NA) yang baru dengan metode cawan gores (Streak plate) dan diinkubasi pada suhu $37^{\circ} \mathrm{C}$ selama $1 \times 24$ jam. Isolat bakteri yang menunjukkan satu jenis isolat bakteri merupakan isolat yang sudah murni, sedangkan isolat bakteri yang belum murni akan dimurnikan lagi sampai didapatkan isolat murni.

5) Pemurnian Isolat Jamur

Isolat jamur yang diperoleh dari isolasi dengan ciri yang berbeda berdasarkan morfologi seperti warna, bentuk koloni dan permukaan koloni, selanjutnya dimurnikan dengan memindahkan isolat jamur ke dalam medium Potato Dextrose Agar (PDA) yang baru dengan metode cawan gores (Streak plate) dan diinkubasi pada suhu $37^{\circ} \mathrm{C}$ selama $3 \times 24$ jam.

6) Pengamatan Morfologi Koloni Bakteri Koloni bakteri yang tumbuh di media agar NA diamati morfologinya. Pengamatan morfologi meliputi bentuk koloni, tepian serta elevasi. Setelah itu diambil gambar koloni bakteri.

7) Pewarnaan Bakteri

Inokulat bakteri digoreskan pada kaca objek, lalu difiksasi. Diwarnai dengan larutan kristal violet selama 30 detik, dibilas dengan aquades. Diwarnai dengan larutan iodium selama 30 detik, dibilas dengan aquades. Dicuci dengan alkohol selama 10-20 detik, dibilas dengan aquades. Diwarnai dengan larutan safranin selama 30 detik, lalu dibilas dengan aquades. Kelebihan air dihilangkan dengan tisu, lalu diamati di bawah mikroskop.

8) Pengamatan Morfologi Koloni Jamur Karakter isolat jamur yang diamati meliputi pertumbuhan koloni (hingga hari ke-3), diameter koloni (hingga hari ke-3), warna koloni dan warna sebalik koloni. Morfologi mikroskopis yang diamati adalah berupa sel (uniseluler/ multiseluler), hifa (berseptum atau tidak, berpigmen gelap atau hialin), reproduksi (seksual atau aseksual), percabangan hifa dan spora aseksual (bentuk, warna, permukaan dan diameter).

9) Identifikasi Isolat Jamur Rizosfer Antagonis

10) Uji Antagonis terhadap JAP (Jamur Akar Putih)

Isolat bakteri dan jamur yang sudah murni diuji antagonis terhadap jamur akar putih (Rigidoporus microporus) dengan menanam satu plong JAP di salah satu sisi cawan petri yang berisi media PDA (Potato Dextrose Agar) dan di sisi yang berlawanan ditanam satu jarum ose isolat bakteri yang telah dimurnikan (Gambar 1). Zona hambat yang terbentuk selama 8 - 10 hari diamati. 


\section{HASIL DAN PEMBAHASAN}

\section{Isolasi Jamur Rizosfer Tanaman Lidah Mertua}

Terdapat perbedaan warna, bentuk, dan morfologi dari koloni bakteri dan jamur yang terdapat di rizosfer tanaman lidah mertua (Tabel 1). Berdasarkan hasil diperoleh sebanyak 7 isolat yang ditemukan pada isolasi jamur rizosfer dari tanaman lidah mertua. Isolat jamur tersebut diberi kode JA-1, JA-2, JA-3, JA-4, JA-5, JA-6, dan JA-7. Berdasarkan hasil seleksi yang dilakukan terhadap 7 isolat tersebut terdapat 4 isolat yang antagonis terhadap jamur akar putih, seperti terdapat pada Tabel 1.

Tabel 1 menunjukkan bahwa terdapat 4 isolat jamur yang bersifat antagonis terhadap pertumbuhan jamur akar putih. Isolat yang bersifat antagonis tersebut adalah isolat jamur dengan kode isolat JA-1, JA-3, JA-4 dan JA-5. Kemampuan dari keempat jamur yang antagonis dalam menghambat penyakit jamur akar putih berbeda pada masing-masing isolat, hal ini disebabkan karena perbedaan kemampuan antagonis yang berbeda pada masingmasing isolat tersebut. Seperti perbedaan kandungan senyawa antibiotik yang terdapat pada tiap isolat jamur. Perbedaan sifat antagonistik tiap spesies jamur antagonis didasarkan pada kemampuan jamur tersebut dalam beradaptasi, bersaing, dan perbedaan senyawa yang dihasilkan oleh masing-masing isolat jamur antagonis tersebut (Anonim², 2008).

Hasil morfologi visual jamur rizosfer dengan menggunakan media PDA dan media MEA disajikan pada Tabel 2. Semua isolat pada media MEA menunjukkan ciri yang sama (diameter koloni lebih besar dibandingkan pada media PDA). Perbedaan besar koloni antara media PDA dan MEA dapat disebabkan oleh perbedaan komposisi nutrien yang tersedia pada kedua media. Media MEA merupakan media yang mempunyai komposisi nutrien yang cocok untuk pertumbuhan fungi tanah. Media MEA merupakan media yang sangat baik khususnya untuk fungi tanah dibandingkan media lain seperti PDA (Anonim ${ }^{1}$, 2006).
Berdasarkan pengamatan secara visual meliputi struktur reproduktif dan struktur non-reproduktif (Tabel 3), semua isolat jamur yang bersifat antagonis merupakan jamur kelompok kapang. Hal ini dapat dilihat dari struktur somatik (tubuh) berupa hifa yang membentuk miselium. Berdasarkan ada tidaknya septat pada hifa, keempat isolat yang diperoleh terdapat 3 isolat yang memiliki septat yaitu JA-1, JA-3, JA-5 dan 1 isolat yang tidak mempunyai septat yaitu JA-4.

Berdasarkan karakteristik morfologi baik makroskopis dan mikroskopis, dua isolat yaitu JA-1 dan JA-5 memenuhi karakter yang menunjukkan genus Aspergillus. Karakter kedua isolat tersebut ditunjukkan pada Gambar 2. Karakteristik morfologi mikroskopis menunjukkan bahwa isolat JA-1 merupakan Aspergillus fumigatus dan JA-5 merupakan Aspergillus niger. Selanjutnya, isolat JA-4 memenuhi karakter genus Mucor dengan spesies Mucor racemous dan isolat JA-3 memenuhi karakter genus Trichoderma dengan spesies Trichoderma harzianum. Karakter isolat tersebut ditunjukkan pada Gambar 3.

Isolat JA-3 yaitu Trichoderma harzianum merupakan isolat jamur yang sudah dipergunakan untuk menekan pertumbuhan jamur penyebab penyakit akar putih dari tanaman karet. Menurut Whipps (1991) dalam Yundasari (1996), bahwa jamur Trichoderma harzianum merupakan jamur yang menghasilkan antibiotik gliotixin, viridin dan pertumbuhannya yang cepat sehingga mampu menyerang jamur lain untuk mendapatkan nutrisi. Trichoderma harzianum ini juga menghasilkan enzim $\beta$-glukanase yang dapat menghancurkan dinding sel miselia jamur lain sehingga jamur ini dapat menekan pertumbuhan jamur akar putih yang dinding selnya terdiri dari kitin. Selanjutnya, isolat JA-1 dan JA-5 yaitu Aspergillus niger dan Aspergillus fumingatus. Kedua jamur ini memiliki senyawa antibiotik dan enzim yang dapat mendegradasi kitin yang menyusun dinding sel jamur patogen. Menurut Rao (1994) bahwa jamur Aspergillus niger dan Aspergillus fumingatus merupakan jamur yang menghasilkan senyawa antibiotik dan bersifat khitinolitik sehingga mampu menghambat pertumbuhan dari jamur patogen. 
Penapisan jamur dan bakteri antagonis terhadap jamur akar putih (Rigidoporus microporus) dari rizosfer tanaman lidah mertua (Sansevieria trifasciata Prain)

Tabel 1. Seleksi jamur yang bersifat antagonis terhadap pertumbuhan jamur akar putih (Rigidoporus micoporus) pada medium PDA padat

Table 1. Selection of fungi antagonistic to the growth of white root fungi (Rigidoporus micoporus) on solid PDA medium

\begin{tabular}{|c|c|c|c|c|c|}
\hline \multirow{2}{*}{$\begin{array}{l}\text { Kode isolat } \\
\text { Isolate code }\end{array}$} & \multicolumn{3}{|c|}{$\begin{array}{cc}\text { Diameter Rigidoporus microporus } \\
\text { Diameter of Rigidoporus microporus } \\
(\mathrm{cm})\end{array}$} & \multirow{2}{*}{$\begin{array}{l}\text { Rata - } \\
\text { rata } \\
\text { Average }\end{array}$} & \multirow{2}{*}{$\begin{array}{l}\text { Keterangan } \\
\text { Description }\end{array}$} \\
\hline & $\begin{array}{c}\text { Hari ke-3 } \\
3^{r d} \text { day }\end{array}$ & $\begin{array}{c}\text { Hari Ke- } 6 \\
6^{\text {th }} \text { day }\end{array}$ & $\begin{array}{c}\text { Hari-Ke } 9 \\
9^{t h} d a y\end{array}$ & & \\
\hline $\begin{array}{l}\text { Kontrol } \\
\text { Control }\end{array}$ & 1,558 & 3,917 & 4,500 & 3,32 & \\
\hline JA-1 & 1,667 & 2,000 & 1,975 & 1,87 & + \\
\hline JA-2 & 1,583 & 3,017 & 3,150 & 2,58 & - \\
\hline JA-3 & 1,467 & 2,215 & 1,192 & 1,62 & + \\
\hline $\mathrm{JA}-4$ & 1,333 & 1,508 & 1,392 & 1,40 & + \\
\hline JA-5 & 1,158 & 1,050 & 0,692 & 0,96 & + \\
\hline JA-6 & 1,600 & 3,250 & 3,917 & 2,92 & - \\
\hline JA-7 & 1,567 & 3,000 & 3,059 & 2,53 & - \\
\hline
\end{tabular}

$>2 \mathrm{~cm}$ : - : Tidak antagonis terhadap Rigidoporus microporus

Not antagonistic toward Rigidoporus microporus

$<2 \mathrm{~cm}$ : + : Bersifat antagonis terhadap Rigidoporus microporus

Antagonistic toward Rigidoporus microporus

Tabel 2. Morfologi makroskopis jamur rizosfer yang bersifat antagonis terhadap jamur Rigidoporus microporus pada medium PDA dan MEA

Table 2. Macroscopic morphology of the antagonistic rhizosphere fungi to Rigidoporus microporus on PDA and MEA media

\begin{tabular}{|c|c|c|c|c|c|c|c|c|}
\hline \multirow[b]{2}{*}{$\begin{array}{l}\text { Kode } \\
\text { Isolat } \\
\text { Isolate } \\
\text { code }\end{array}$} & \multicolumn{4}{|c|}{$\begin{array}{l}\text { Media PDA } \\
\text { PDA medium }\end{array}$} & \multicolumn{4}{|c|}{$\begin{array}{l}\text { Media MEA } \\
M E A \text { medium }\end{array}$} \\
\hline & $\begin{array}{l}\text { Pertumbuhan } \\
\text { Growth }\end{array}$ & $\begin{array}{l}\text { Diameter } \\
(\mathrm{cm})\end{array}$ & $\begin{array}{l}\text { Warna } \\
\text { koloni } \\
\text { Colony } \\
\text { color }\end{array}$ & $\begin{array}{c}\text { Warnasebalik } \\
\text { koloni } \\
\text { Colony reverse } \\
\text { color }\end{array}$ & $\begin{array}{l}\text { Pertumbuha } \\
\text { Growth }\end{array}$ & $\begin{array}{l}\text { Diameter } \\
(\mathrm{cm})\end{array}$ & $\begin{array}{l}\text { Warna } \\
\text { koloni } \\
\text { Colony } \\
\text { color }\end{array}$ & $\begin{array}{l}\text { Warna } \\
\text { sebalik } \\
\text { koloni } \\
\text { Colony } \\
\text { reverse } \\
\text { color }\end{array}$ \\
\hline JA-1 & Cepat & 4,40 & Hijau & Coklat muda & Cepat & 4,600 & Hijau & Hijau \\
\hline JA-3 & Cepat & 4,90 & $\begin{array}{l}\text { Hijau } \\
\text { keputih- } \\
\text { putihan }\end{array}$ & $\begin{array}{l}\text { Putih } \\
\text { kecoklatan }\end{array}$ & Cepat & 4,025 & $\begin{array}{l}\text { Hijau } \\
\text { keputih- } \\
\text { putihan }\end{array}$ & $\begin{array}{l}\text { Hijau } \\
\text { tua }\end{array}$ \\
\hline JA-4 & Cepat & 4,35 & $\begin{array}{l}\text { Putih } \\
\text { Hitam }\end{array}$ & Putih & Cepat & 4,125 & Putih & Putih \\
\hline JA-5 & Cepat & 3,70 & kehijauan & $\begin{array}{c}\text { Coklat } \\
\text { kehijauan }\end{array}$ & Cepat & 3,730 & $\begin{array}{c}\text { Hitam } \\
\text { kehijauan }\end{array}$ & $\begin{array}{c}\text { Hijau } \\
\text { kehitaman }\end{array}$ \\
\hline
\end{tabular}

$+\quad$ 1: Pertumbuhan lambat $<2 \mathrm{~cm}$

Slow growth $<2 \mathrm{~cm}$

++ : Pertumbuhan cepat $>3 \mathrm{~cm}$

Fast growth $>3 \mathrm{~cm}$ 
Tabel 3. Karakteristik morfologi mikroskopis tiap isolat jamur yang bersifat antagonis terhadap jamur Rigidoporus microporus

Table 3. Microscopic morphological characteristic of each isolate antagonistic to fungal Rigidoporus microporus

\begin{tabular}{|c|c|c|c|c|}
\hline \multirow{2}{*}{$\begin{array}{l}\text { Karakter } \\
\text { Character }\end{array}$} & \multicolumn{4}{|c|}{$\begin{array}{l}\text { Kode isolat jamur } \\
\text { Code of fungal isolate }\end{array}$} \\
\hline & JA-1 & JA-3 & JA-4 & JA-5 \\
\hline \multicolumn{5}{|c|}{$\begin{array}{l}\text { Struktur non reproduktif } \\
\text { Non reproductive structure }\end{array}$} \\
\hline Hifa & & & & \\
\hline Septat/aseptat & Septat & Septat & Aseptat & Septat \\
\hline Warna hifa & Hialin & Hialin & Hialin & Hialin \\
\hline \multicolumn{5}{|c|}{$\begin{array}{l}\text { Struktur reproduktif } \\
\text { Reproductive structure }\end{array}$} \\
\hline $\begin{array}{l}\text { Spora } \\
\text { - Bentuk }\end{array}$ & - & - & $\stackrel{+}{\text { Bulat }}$ & - \\
\hline - Ukuran & & & $\pm 6 \mu \mathrm{m}$ & \\
\hline - Permukaan & & & Halus & \\
\hline - Warna & & & Abu-abu & \\
\hline Kolumela & - & - & + & - \\
\hline Sporangiofor & - & - & + & - \\
\hline $\begin{array}{l}\text { Konidia } \\
\text { - Bentuk }\end{array}$ & $\stackrel{+}{+}$ & $\begin{array}{c}+ \\
\text { Lonjong }\end{array}$ & - & $\stackrel{+}{+}$ \\
\hline - Permukaan & Berduri & Halus & & Kasar \\
\hline - Warna & Hijau & Hialin & & Hitam kecoklatan \\
\hline Konidiofor & + & + & - & + \\
\hline - Fialid & + & + & - & + \\
\hline - Metula & + & + & - & + \\
\hline - Vesikel & + & + & - & + \\
\hline - Stipe & + & + & - & + \\
\hline Hasil identifikasi & $\begin{array}{l}\text { Aspergillus } \\
\text { fumingatus }\end{array}$ & Tricoderma harzianum & $\begin{array}{l}\text { Mucor } \\
\text { raceosus }\end{array}$ & Aspergillus niger \\
\hline
\end{tabular}

Isolasi Bakteri dari Rizosfer Tanaman Lidah Mertua

Sebanyak 11 isolat bakteri yang diperoleh dari rhizosfer tanaman lidah mertua telah dikarakterisasi morfologi selnya, meliputi bentuk koloni bakteri di dalam media NA, tepian, elevasi, serta reaksi pewarnaan gram (Tabel 4). Dari Tabel 4, dapat dilihat bahwa secara umum, bentuk koloni bakteri adalah irregular and spreading (tidak beraturan dan menyebar), tepian berbentuk lobate (berlekuk) serta elevasi antara flat (datar) dan raised (timbul). Sebanyak 4 isolat termasuk ke dalam kelompok bakteri gram positif, 7 isolat termasuk bakteri gram negatif. 


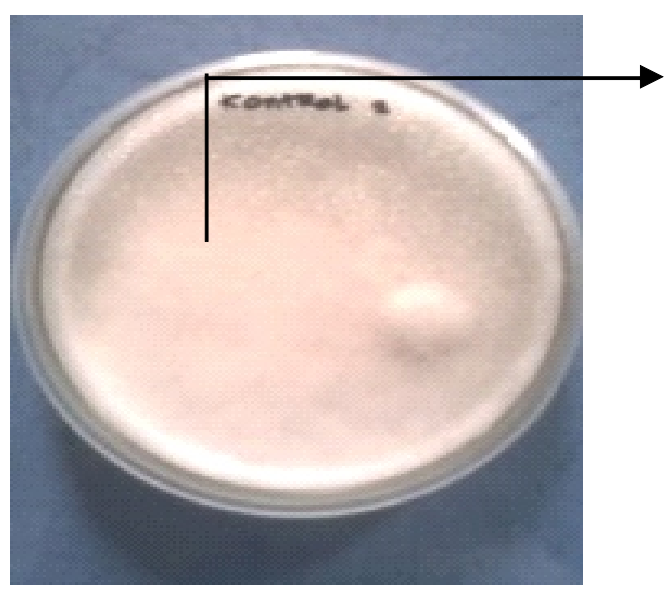

(a)

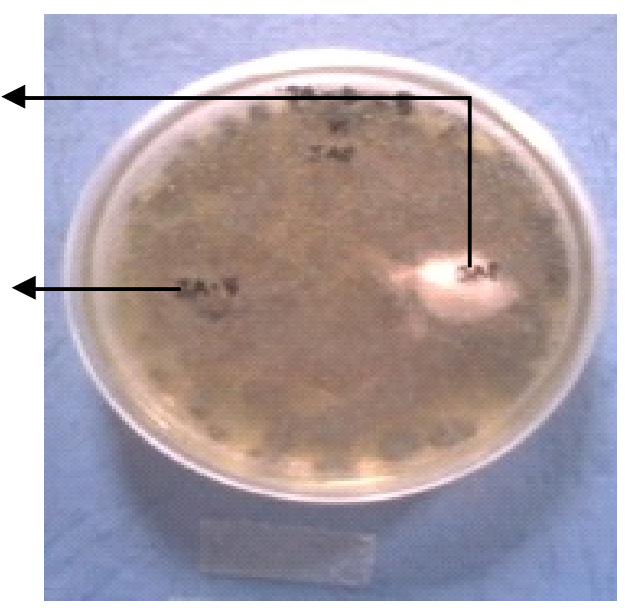

(b)

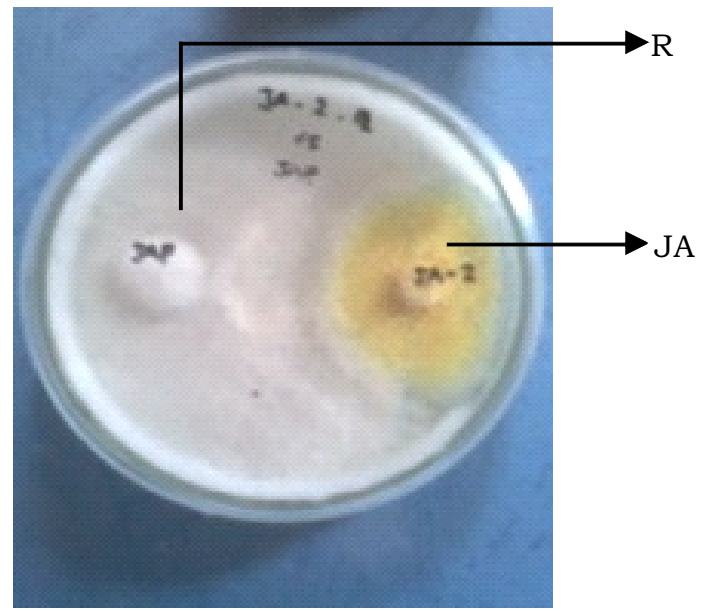

(c)

Gambar1. Uji antagonis jamur Rigidoporus microporus pada media PDA padat

(a) Kontrol (b) isolat yang bersifat antagonis (c) isolat yang tidak antagonis

(R) : Rigidoporus microporus, JA : jamur antagonis (fungal antagonists)

Figure 1. Antagonist test of Rigidoporus microporus on solid PDA media

(a) Control (b) antagonistic isolate (c) not antagonistic isolate

$(R)$ : Rigidoporus microporus, JA : jamur antagonis (fungal antagonists)

Pengelompokan bakteri berdasarkan reaksi pewarnaan gram menunjukkan adanya perbedaan komposisi makromolekul di antara bakteri gram positif dan negatif. Menurut Anonim ${ }^{2}$ (2008), bakteri grampositif adalah bakteri yang mampu mempertahankan zat warna metil ungu sewaktu proses pewarnaan gram. Bakteri jenis ini akan berwarna biru atau ungu di bawah mikroskop, sedangkan bakteri gramnegatif akan berwarna merah atau merah muda. Perbedaan klasifikasi antara kedua jenis bakteri ini terutama didasarkan pada perbedaan struktur dinding sel bakteri.
Pengujian 11 isolat bakteri rizosfer lidah mertua terhadap jamur akar putih (Rigidoporus microporus) menunjukkan terdapat dua isolat yang bersifat antagonis terhadap jamur akar putih yaitu L.M. 5 dan L.M. 6. Hal ini ditunjukkan dengan panjang jari-jari koloni pada hari kedelapan yang lebih pendek dibandingkan dengan kontrol dan isolat yang lainnya (Tabel 5).

Penghambatan pertumbuhan koloni JAP oleh isolat bakteri L. M. 5 lebih baik dibandingkan dengan isolat bakteri L. M. 6, dimana pertumbuhan koloni jamur akar 


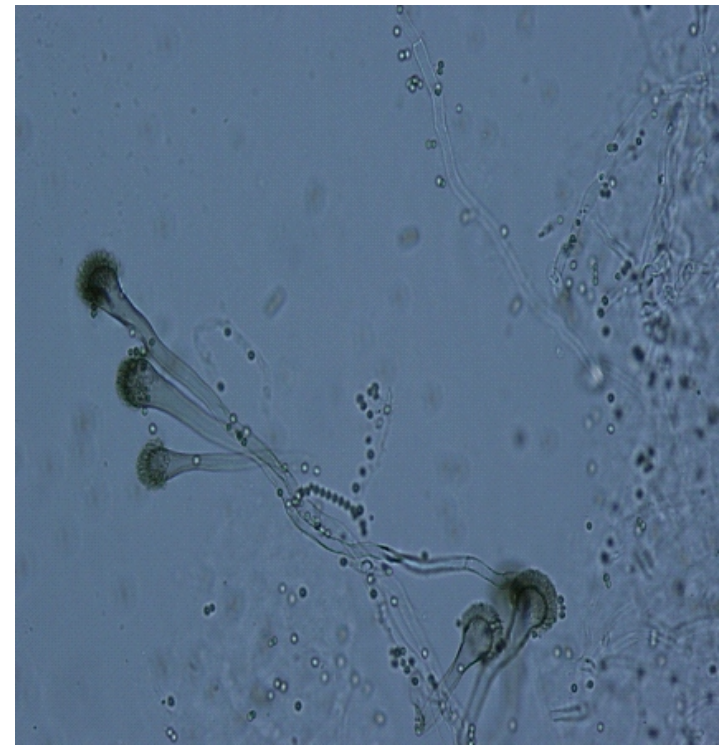

$\mathrm{JA}-1$

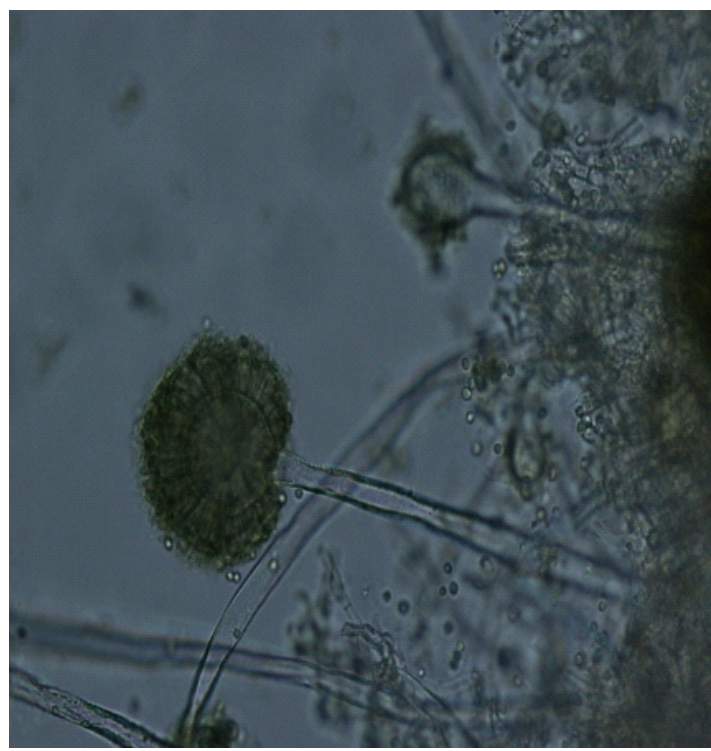

JA-5

Gambar 2. Dua isolat yang memiliki karakter genus Aspergillus (perbesaran 1000x )

Figure 2. Two isolates with Aspergillus genus character (magnified 1000x)

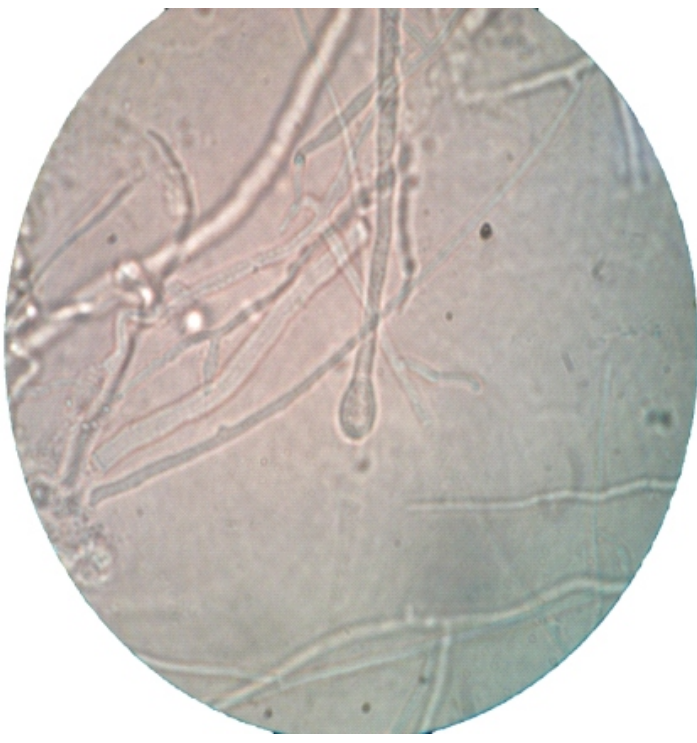

$\mathrm{JA}-4$

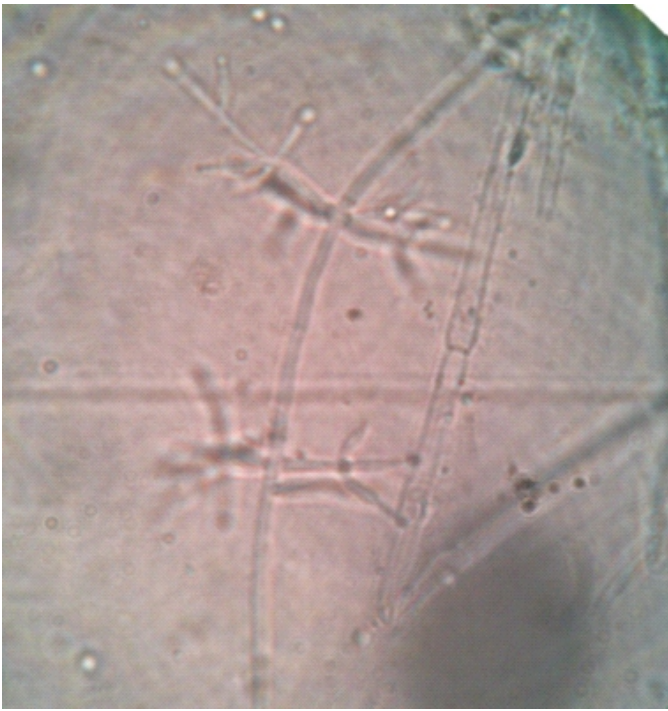

JA-3

Gambar 3. Morfologi mikroskopis isolat JA-4 (Mucor racemous Fres) dan JA-3 (Trichoderma harzianum)

Figure 3. Microscopic morphology of JA-4 isolates (Mucor racemous) Fres and JA-3 (Trichoderma harzianum) 
putih hanya berjari-jari 3,7 cm, sedangkan pada isolat bakteri L. M. 6, pertumbuhan koloni jamur akar putih berjari-jari 4,3 cm, panjang jari-jari koloni JAP pada hari ke enam dan kedelapan (Gambar 4) dan antagonis isolat L.M.5 dan L.M.6 (Gambar 5).

Pada isolat L.M. 6 dan isolat L. M. 5 pertumbuhan panjang jari-jari koloni jamur akar putih sudah terhenti pada hari keenam, hal ini disebabkan adanya mekanisme perlawanan dari bakteri pada setiap isolat. Kondisi ini berbeda dengan perlakuan kontrol dari isolat yang lain, dimana jari-jari koloni terus berkembang sampai selesai pengamatan, setiap bakteri antagonis memiliki kemampuan yang berbeda dalam menghambat pertumbuhan koloni jamur akar putih. Hal ini didukung oleh pendapat Sutedjo et al., (1991) yang menyatakan bahwa perbedaan kemampuan antagonis atau terbentuknya mekanisme perlawanan

Tabel 4. Morfologi koloni bakteri pada medium Nutrien Agar (NA)

Table 4. Morphology of bacterial colonies on Nutrient Agar (NA) medium

\begin{tabular}{|c|c|c|c|c|}
\hline No & $\begin{array}{l}\text { Bentuk koloni } \\
\text { Colony shape }\end{array}$ & $\begin{array}{l}\text { Tepian } \\
\text { Edge }\end{array}$ & $\begin{array}{l}\text { Elevasi } \\
\text { Elevation }\end{array}$ & $\begin{array}{c}\text { Reaksi } \\
\text { pewarnaan gram } \\
\text { Gram staining } \\
\text { reaction }\end{array}$ \\
\hline 1 & Irregular \& spreading & Lobate & Flat & Merah \\
\hline 2 & Irregular \& spreading & Lobate & Flat & Merah \\
\hline 3 & Irregular \& spreading & Branching & Raised & Merah \\
\hline 4 & Irregular \& spreading & Wavy & Flat & Merah \\
\hline 5 & Irregular \& spreading & Lobate & Raised & Merah \\
\hline 6 & Round with radiating margins & Lobate & Raised & Ungu \\
\hline 7 & Irregular \& spreading & Lobate & Flat & Ungu \\
\hline 8 & Irregular \& spreading & Lobate & Flat & Ungu \\
\hline 9 & Round & Lobate & Flat & Merah \\
\hline 10 & Round with scalloped margins & Lobate & Raised & Ungu \\
\hline 11 & Concentric & Lobate & Raised & Merah \\
\hline
\end{tabular}

Tabel 5. Panjang jari-jari koloni jamur akar putih hari ke-8

Table 5. Length of radius of colony at $8^{\text {th }}$ day

\begin{tabular}{ccc}
\hline No & $\begin{array}{c}\text { Perlakuan jenis bakteri } \\
\text { Treatment of bacterial species }\end{array}$ & $\begin{array}{c}\text { Panjang jari-jari koloni hari ke-8 } \\
\text { Radius of colony at } 8^{\text {th }} \text { day }\end{array}$ \\
\hline 1. & Kontrol & 8,5 \\
2. & Isolat L. M. 1 & 7,9 \\
3. & Isolat L. M. 2 & 8,3 \\
4. & Isolat L. M. 3 & 8,0 \\
5. & Isolat L. M. 4. & 8,1 \\
6. & Isolat L. M. 5 & 3,7 \\
7. & Isolat L. M. 6 & 4,3 \\
8. & Isolat L. M. 7 & 8,4 \\
9. & Isolat L. M. 8 & 8,4 \\
10. & Isolat L. M. 9 & 4,4 \\
11. & Isolat L. M. 10 & 7,2 \\
12. & Isolat L. M. 11 & 7,8 \\
\hline
\end{tabular}




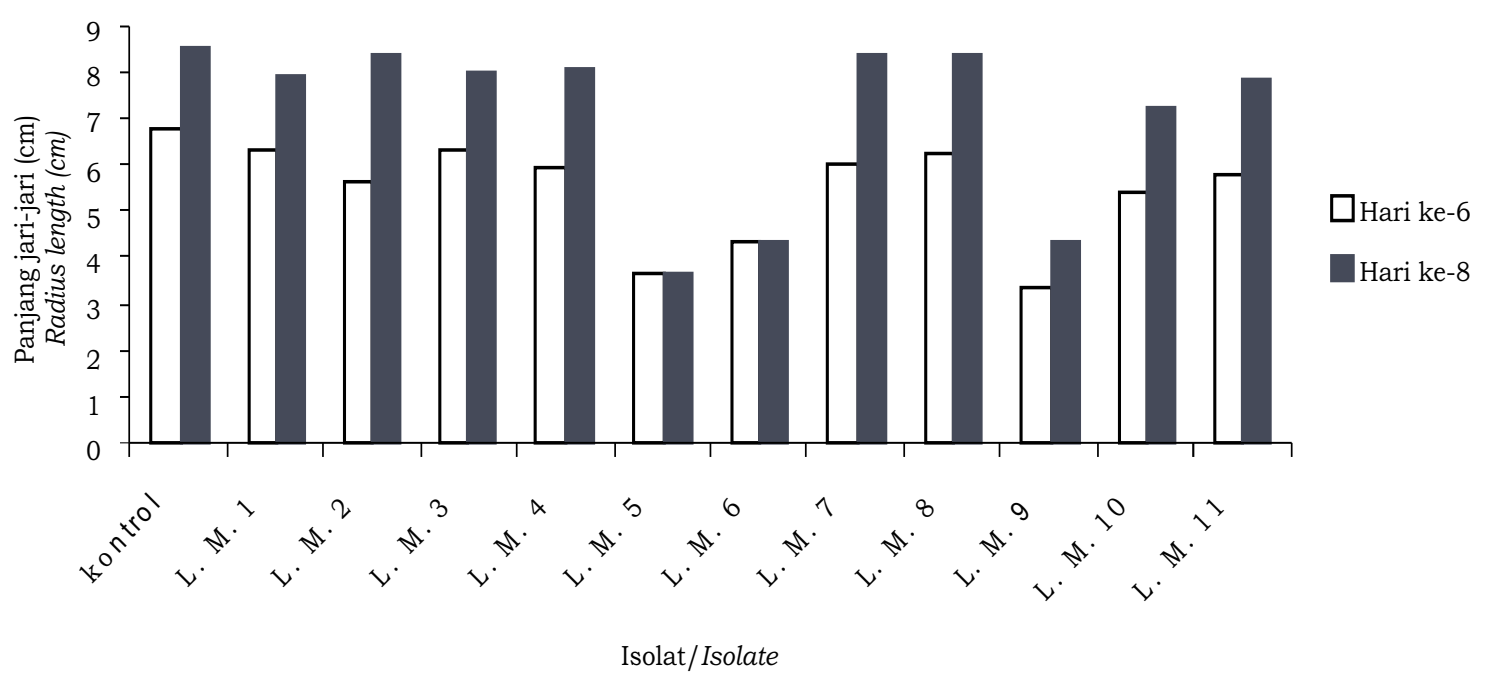

Gambar 4. Panjang jari-jari isolat bakteri rizosfer

Figure 4. Radius of rhizosfer bacterial isolates

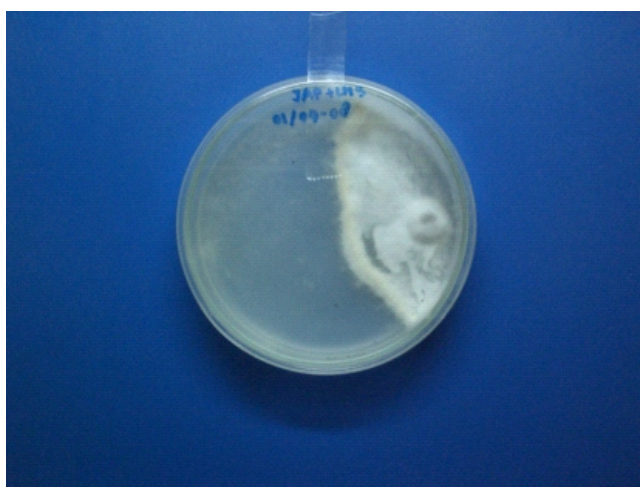

$\mathrm{A}=$ isolat L. M. 5

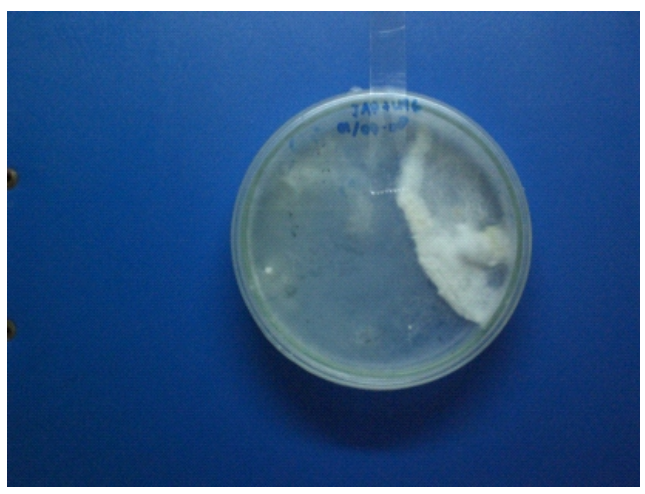

$\mathrm{B}=$ isolat L. M. 6

Gambar 5. Antagonisme isolat bakteri rizosfer lidah mertua terhadap Rigidosporus microporus dalam media PDA

Figure 5. Antagonism of rhizosphere bacterical isolates of snake plant towards Rigidosporus microporus on PDA medium

suatu organisme terhadap organisme lainnya ditentukan oleh banyak faktor, diantaranya nutrisi dalam suatu media adanya perubahan fisika kimia suatu organisme yang ditunjukkan sebagai suatu aksi dalam sesuatu jarak, dan produksi serta pembebasan substansi-substansi spesifik (zat-zat khusus) oleh jasad renik tertentu yang bersifat bakterisidal yang selektif atau fungisidal atau disebut juga antibiotika.

Belum seluruhnya dapat dijelaskan dengan cara bagaimana mikroorganisme antagonis mempengaruhi populasi patogen, tetapi umumnya mekanisme tersebut dihubungkan dengan salah satu dari empat pengaruh yaitu (1) parasitisme dan membunuh patogen secara langsung; (2) berkompetisi dengan patogen dalam hal makanan; (3) toksin yang langsung mempengaruhi patogen dengan zat antibiotik yang dilepaskan oleh antagonis; dan (4) toksin yang tidak langsung mempengaruhi patogen melalui zat yang mudah menguap, seperti etilen, yang dilepaskan oleh aktivitas metabolik antagonis (Agrios, 1997). 


\section{KESIMPULAN}

Terdapat 11 jenis bakteri rhizosfer dan 7 jenis jamur hasil ekplorasi tanaman lidah mertua dari hasil pengamatan di laboratorium. Dari 11 jenis bakteri tersebut terdapat 4 tergolong bakteri gram positif dan 7 tergolong bakteri gram negatif dan 2 jenis bakteri yang bersifat antagonis terhadap jamur akar putih dan dari 7 jenis jamur yang ditemukan terdapat 4 isolat jamur yang bersifat antagonis.

\section{DAFTAR PUSTAKA}

Agrios, G. N. 1997. Plant Pathology $4^{\text {th }}$ Edition. Academic Press, New York.

Anonim ${ }^{1}$. 2006. Antagonis. www.pangkalan dataopt.net

Anonim². 2008. Pewarnaan Gram. www.wikipedia.org

Dalimartha, S. 2000. Atlas Tumbuhan Obat Indonesia Jilid 1. Trubus Agriwidya, Ungaran

Mursito, B. 2000. Tampil Percaya Diri dengan Ramuan Tradisional. Penebar Swadaya, Depok

Purwaningsih, S. 2003. Isolasi, populasi dan karakterisasi bakteri pelarut fosfat pada tanah dari tanaman nasional Bogani Nani Wartabone Sulawesi Utara. Berkala Ilmiah Biologi, 3(1), 4553.
Rao, S. 1994. Mikroorganisme Tanah dan Pertumbuhan Tanaman. Edisi kedua. Universitas Indonesia, Jakarta.

Situmorang, A,. H. Suryaningtyas, and T.R. Febbiyanti. 2007. Control of white root disease using antagonistic plant on rubber plantation. Proc. Int. Workshop on White Root Disease of Hevea Rubber. IRRDB. Salatiga, Indonesia.

Susilowati, D.N, S. Rasti, Elsanti dan Y. Erny. 2003. Isolasi dan Seleksi Mikroba Diazotrof Endofilik dan Penghasil Zat Pemacu Tumbuh pada Tanaman Padi dan Jagung. Balai Penelitian Bioteknologi dan Sumber Daya Genetik Petanian, 128-144,

Sutedjo, M. K dan Sastroadmodjo. 1991. Mikrobiologi Tanah. Rineka Cipta. Jakarta.

Wijayakusuma, H.M., S. Dalimartha dan A.S. Wirian. 1995. Tanaman Berkhasiat Obat di Indonesia. Jilid ke2. Pustaka Kartini, Jakarta

Wijayakusuma, H.M., S. Dalimartha dan A.S. Wirian, 1996. Tanaman Berkhasiat Obat di Indonesia. Jilid ke3. Pustaka Kartini, Jakarta

Yundasari, V. 1996. Jenis-Jenis Jamur pada Bambu Hitam (Gigantochlea atroviolaceae). Jurusan Biologi FMIPA. Universitas Sriwijaya. 